\title{
Macroeconomic Conditions and Stock Market Liquidity in Kenya
}

\author{
Rogers Ochenge ${ }^{1,2}$, Peter Muriu $^{3} \&$ Rose Ngugi $^{3}$ \\ ${ }^{1}$ A PhD Candidate, University of Nairobi, Nairobi, Kenya \\ ${ }^{2}$ Teaching Fellow, University of Embu and KCA University, Kenya \\ ${ }^{3}$ Senior Lecturer, School of Economics, University of Nairobi, Nairobi, Kenya \\ Correspondence: Rogers Ochenge, PhD Candidate, University of Nairobi; Teaching Fellow, University of Embu \\ and KCA University, Kenya. E-mail: rochenge@yahoo.co.uk
}

Received: September 26, 2020

Accepted: November 9, 2020

Online Published: November 18, 2020

doi:10.5539/ijef.v12n12p47

URL: https://doi.org/10.5539/ijef.v12n12p47

\begin{abstract}
This paper explores the role of macroeconomic conditions on systematic stock market liquidity in Kenya. The study first estimates the monthly probability of liquidity switching from a high to a low liquidity state using the Markov regime switching framework. Then, using ordinary least squares, the study identifies macro factors that significantly drive liquidity fluctuations. Importantly, monetary policy changes, exchange rate fluctuations and global risk aversion are found to significantly explain the resilience of stock market liquidity. Understanding the specific macroeconomic variables that drive liquidity fluctuations helps investors to monitor their liquidity exposures further enabling them to make informed investment choices. This ultimately leads to efficient resource allocation. Additionally, the empirical findings of this study provide key information to financial market supervisors regarding which macro variables to watch in their surveillance duties.
\end{abstract}

Keywords: liquidity regimes, liquidity resilience, macroeconomic conditions

JEL classification: G12, G180.

\section{Introduction}

Liquidity, which is the ease with which traders can buy and sell securities is a fundamental attribute of a well-functioning stock market. Importantly, low stock market liquidity in emerging markets has, in the past, been cited as a significant constraint to domestic economic development (Levine, 1991; Bencivenga \& Smith, 1991; Adjasi \& Yartey, 2007; Hearn et al., 2010; Brandao-Marques, 2016). More specifically, since illiquidity is often priced in the market (see for example, Amihud \& Mendelson, 1986; Datar, Naik, \& Radcliffe, 1998; Amihud, 2002, Hearn, 2009; Hearn, Piesse, \& Strange, 2010; Minovic \& Zivkovic, 2012 among others), illiquid stock markets may drive up the cost of raising equity. The elevated levels of cost of equity can have adverse effect on private equity activity. That is, if illiquidity raises the cost of equity then this makes initial stock public offerings (IPOs) unattractive. This can discourage innovation and firm growth since young firms tend to rely on funding sources such as IPOs. Additionally, illiquid stock markets are often associated with frequent asset mispricing which may lead to capital misallocation and financial system fragility (Brandao-Marques, 2016).

Given the importance of market liquidity, policy makers are often interested in understanding what drives liquidity. Traditionally, the finance literature largely focused on the microstructure determinants of stock market liquidity. However, in the last 15 years there has been a growing interest in understanding whether macroeconomic factors drive stock market liquidity. For example, Soderberg (2008) observes that after the events of the 2008 global financial crisis, the interest in the linkage between the state of the macro economy and aggregate market liquidity has grown remarkably. Generally, a link between macroeconomic conditions and stock market liquidity can arise since macroeconomic shocks are capable of simultaneously altering the risk of many firms and therefore affecting trading activity across numerous firms. Indeed, a fast expanding finance literature indicate that macroeconomic factors can explain the existence of co-movement of liquidity across many stocks (a phenomenon known as commonality-in-liquidity) documented by several authors (such as Chordia et al., 2000; Huberman \& Halka, 2001; Hasbrouck \& Seppi, 2001; Brockman \& Chung, 2002; Pukthuanthong-Le \& Visaltanachoti, 2009; Brockman et al., 2009; Koch et al., 2016 among others). Commonality in liquidity matters to policy authorities, particularly central bankers because shocks to market-wide liquidity can spillover to individual firms and precipitate a financial system collapse (Fernando, 
2003). Thus, it is quite relevant to examine which and how macroeconomic variables influence aggregate stock market liquidity.

Although Chordia, Roll, and Subrahmanyam (2001) emphasized on the lack of theoretical link between macroeconomic changes and stock liquidity changes, there have been new theoretical developments since then. Particularly, recent theoretical literature links stock market liquidity to either business cycles (Eisfeldt, 2004), monetary policy changes (Brunnermeier \& Pedersen, 2009) or investor flows (Massa, 2004). Interestingly, empirical studies examining the role of these variables on liquidity yield mixed results. For example, Fujimoto (2003) find that macroeconomic conditions influence liquidity in times of market turbulence but have negligible effect in good economic times. Soderberg (2008) drawing evidence from the Scandinavian economies also shows that the response of stock liquidity to macroeconomic shocks can significantly vary from one market to another. Further, Soderberg argue that there might be significant differences across quote-driven and order-driven markets in regard to the relationship between macroeconomic variables and market liquidity.

Motivated by the existence of mixed-results regarding the role of macroeconomic shocks on stock liquidity coupled with the observation that the relationship might vary across markets, this study examines the empirical link between macroeconomic variables and stock market liquidity in the case of a frontier order driven market namely the Nairobi securities exchange (NSE), Kenya. The NSE is characterized by low and discontinuous liquidity. For example, anecdotal evidence reveals that, except for a few large stocks, several listed stocks trade infrequently. Additionally, there is notable fluctuation of liquidity over time especially for small and medium-sized stocks (Hearn et al., 2010). Nyasha and Odhiambo (2014) note that low stock market liquidity is one of the key impediments to the development of the Kenyan stock market. Further, Hearn et al. (2010) finds that the Kenyan stock market has the highest cost of raising equity relative to some selected key stock markets in Sub-Saharan Africa. These authors suggest that illiquidity costs contribute significantly to the high cost of equity.

This study, by focusing on the relation between stock liquidity and macroeconomic conditions, makes a key contribution to the literature on stock market liquidity. That is, this is the first empirical evidence on the response of liquidity to macroeconomic shocks in Kenya. Existing studies are nearly based on the quote driven liquid market of the U.S. Quote-driven stock exchanges have market makers who provide liquidity as opposed to order driven markets where investors provide liquidity. Rehman, Shahnaz, and Zainudin (2016) argue that this distinction can bring about differences in how liquidity is impacted by the state of the economy. Yet, only few studies (in emerging markets) have examined whether and which macroeconomic shocks matter for liquidity in order-driven markets. Indeed, no study has covered the frontier markets. In this regard, the current study is a useful addition to the debate on the role of macroeconomic variables in explaining stock liquidity variations.

\section{Literature Review}

There exists a fast-growing literature which examines the dynamic link between macroeconomic fluctuations and aggregate stock market liquidity. Importantly, the empirical literature appears to follow three strands, that is; the role of fluctuations in national real economic activity (business cycles) on liquidity, the impact of monetary policy, and the global business conditions on local liquidity. We briefly review the development of the literature along these three strands.

On business cycles, several studies find a two-way causality between stock liquidity and macroeconomic conditions. Specifically, Fujimoto (2003), Chordia, Sarkar, and Subrahmanyam (2005), and Goyenko and Ukhov (2009) were among the first papers to carefully study the causality between liquidity and business cycles in the developed stock market of the U.S. These seminal studies indicate that; firstly, industrial production and inflation significantly explain changes in stock market liquidity both at an aggregate as well at firm level. For instance, at firm level, these studies show that small firms are more elastic to business cycles compared to large firms. Secondly, these authors document an asymmetrical effect of business cycles on liquidity. That is, liquidity tends to respond prominently to macroeconomic variables during recessions than it does in booms. Thirdly, the authors also observe that for one to detect the liquidity-business cycles transmission mechanism, a longer time span needs to be considered. Particularly, a researcher needs to subsume several economic shocks so as to understand the dynamic link between stock liquidity business cycles. Recent studies on this relationship on U.S market confirm these observations (see for example, Ellington et al., 2017).

Outside the developed stock market of U.S. several other studies have examined liquidity-business cycle relationship. Soderberg (2008) find evidence of the link between industrial production and inflation on the Scandinavian stock market liquidity. Galariotis and Giouvris (2015) uncover a two-way causality (albeit weak) between domestic macroeconomic conditions and local liquidity for the G7 economies (Canada, France, Germany, Italy, Japan, and UK). Rehman et al. (2016) and Nwaolisa and Chijindu (2016) document a one-way 
long-run causality from economic activity to stock market liquidity in Pakistan and Nigeria respectively. Zheng and $\mathrm{Su}$ (2017) show that oil price-related shocks drive stock market liquidity in China.

On monetary policy, a number of studies indicate that monetary shocks matter for stock market liquidity. Goyenko and Ukhov (2009) show that expansionary monetary policy promotes liquidity while tight monetary policy hurts liquidity in the U.S economy. Fernández-Amador, Gächter, Larch, and Peter (2013) also find that monetary policy drives liquidity for three major stock markets in Europe. Debata and Mahakud (2018) using stock level data from India also finds that expansionary monetary policy is associated to positive improvement in liquidity. These authors conclude that Central Banks should consider incorporating stock market liquidity in their reaction functions.

Over the last 5 years there has been an interesting aspect of monetary policy that has been the focus of financial economists as far as the monetary policy-liquidity debate is concerned. That is, the role of monetary policy communication on fluctuations in stock market liquidity. For example, Lee et al. (2016) finds that improved communication of monetary policy by Korean Central Bank leads to increased local stock liquidity. Importantly, smooth central bank communication of the monetary strategy reduces information asymmetry as well as uncertainty in the formation of expectations by the market participants thereby easing stock trading. Kurihara (2017) however, finds no evidence that monetary policy announcements elicit response from stock market liquidity in Japan.

The last strand of the literature identifies global uncertainties as a key determinant of local stock liquidity. Increased global uncertainties mainly slows foreign trading hurting markets that heavily relies on foreign investors' participation. Rehman et al. (2016) provides evidence that increased foreign equity flows promotes domestic stock liquidity in Pakistan. Brandao-Marques (2016) also show that global risk conditions significantly matter for stock liquidity changes in Chile. Haroon and Rizvi (2020) document that the great uncertainty caused by recent pandemic (COVID-19) significantly reduced stock market liquidity in many emerging markets.

There are several insights drawn from the literature review. Firstly, all empirical studies on the link between macroeconomic conditions and liquidity seem to choose their set of macroeconomic variables from business cycle related, monetary policy related, and investor flows related factors. Secondly, only few studies provide robust results of the impact of macroeconomic factors on liquidity, particularly, when liquidity is measured by different proxies. This is important since liquidity tends to be multidimensional. Indeed, it is observed that in most of these studies researchers only use the Amihud (2002) proxy to capture liquidity. This study attempts to bridge this gap by checking the impact of macroeconomic conditions across several liquidity dimensions.

Thirdly, the linkage between the state of the macro economy and stock liquidity appears to be market specific. That is, liquidity at different stock markets appears to respond differently to different macroeconomic variables. This implies that policy makers cannot simply transfer results in one specific market to another. Indeed, this provides the motivation to study the relationship in the context of the order-driven market of Kenya where the link between economic shocks and liquidity has not been studied before. Besides, most existing studies are skewed towards the advanced quote-driven markets which are often considered to be more liquid relative to the emerging and frontier markets.

\section{Methodology}

The key objective of this study is to examine the role of macroeconomic factors in driving stock market liquidity fluctuations. To this end, the study: first, provides a description of how dependent variable (stock market liquidity fluctuations) is constructed. Secondly, the study then examines the role of macroeconomic factors in explaining the stock market liquidity fluctuations.

\subsection{Modeling Stock Market Liquidity Regimes}

Empirically, market liquidity tends to respond non-linearly to economic shocks (Flood, Liechty, \& Piontek, 2015). Accordingly, an appropriate approach to model liquidity fluctuations would be to take into consideration the abrupt switching of liquidity between different states (such as high and low liquidity). In this regard, this chapter adopts the Markov-Switching dynamic regression model (MS) pioneered by Hamilton (1989) to model stock market liquidity fluctuations in Kenya. Assuming a two-state regime switching process for stock liquidity, the MS model in which the mean and variance of the process switches between two states can be outlined as follows;

$$
L I Q_{t}=\mu_{0}^{s}+\varepsilon_{t}^{s}, \text { for } s=1 \text { or } s=2 \text { and } t=1, \ldots, T .
$$

Where $L I Q_{t}$ represents the monthly liquidity measure (ILLIQ, HH, LM, and LI), and $s$ denotes the liquidity regime. The two states denoted as state 1 (high liquidity) and state 2 (low liquidity) are assumed to follow a 
simple Markov chain process such that the probability of switching from state $i$ in period $t$ to state $j$ in period $t+1$ is given by;

$$
P\left(s_{t+1}=j \mid s_{t}=i\right)=p_{i j}
$$

Thus, the probability of moving from state 1 in one period to state 2 in the next period can be represented as follows;

$$
P\left(s_{t+1}=2 \mid s_{t}=1\right)=p_{12}
$$

The transition probabilities can be given an important economic interpretation in relation to stock market liquidity. For example, the transition probability from state 1 (high liquidity) to state 2 (low liquidity) can be used to gauge the resilience of liquidity. In this regard, liquidity is more resilient if there is a low probability of liquidity transiting to state 2 . High stock market liquidity resilience is key to financial stability since such markets have less elasticity to shocks (Flood, Liechty, \& Piontek, 2015). Accordingly, it is of interest to policy makers to understand what factors can break this resilience. Accordingly, the next section highlights several cyclic factors that are likely to be associated with the resilience of stock market liquidity.

\subsection{Macroeconomic Determinants of Stock Market Liquidity Resilience}

Earlier empirical literature identifies three broad macroeconomics factors with potential to drive stock market liquidity. That is, business cycles related variables (Eisfeldt, 2004), monetary policy variables (Brunnermeier \& Pedersen, 2009), and investor flows variables (Massa, 2004). To capture business-cycle related factors, previous studies employ mainly industrial production and inflation (see for example, Fujimoto, 2003; Chordia et al., 2005; Goyenko \& Ukhov, 2009 among others). Although, there are other several variables that can be used to characterize the business cycles, such as investment, productivity, consumption among others, most of these variables are often reported at a low frequency (mostly annually), making them unattractive in studying financial market variables. Consequently, this study selects monthly Consumer Price Index (CPI) to represent the business cycle.

On monetary policy, this study mainly utilizes the three-month Treasury bill rate (TB) as an indicator of monetary policy stance. The use of TB rate to capture monetary stance draws inspiration from the findings of Goyenko and Ukhov (2009) who show that the shocks to monetary policy are often transmitted to the stock market through the bond market. On investor flows, although, Massa (2004) focused on the role of mutual funds flows, recent literature appears to emphasize on the impact of informed or less informed foreign investors' flows on domestic stock liquidity (Agudelo, 2010; Ding, Nilsson, Suardi, \& others, 2013; Rehman et al., 2016). To empirically examine the influence of foreign investor flows, the would-be ideal indictor is foreign investor net purchases of domestic stocks. However, due to unavailability of this data for the period spanning the entire sample period, this study elects to use three indictors of foreign investor flows: the global risk appetite (as measured by the Chicago Board of Options Exchange volatility index, VIX), the U.S monetary policy rate (that is, the Federal Funds Rate, FFR), and the local Kenyan Shilling to U.S exchange rate (XRATE).

The VIX is a forward-looking indicator measuring the implied risk aversion of international investors. An elevated VIX index implies that investors expect future economic conditions to be bleak. Indeed, the VIX is sometimes called the "fear index". Importantly, it is worth noting, that an increase in the index prompts investors to take flight from risky assets, especially from emerging markets to safe assets in advanced markets such as into U.S Treasury bonds. Such an action will reduce activity in stock markets in emerging and frontier markets thus depressing liquidity in these markets. Similarly, a tight monetary policy stance in the U.S (as indicated by increasing FFR) leads to higher returns of U.S Treasury bonds. This will make international investors to abandon risky assets in emerging and frontier markets for the now attractive U.S Treasury bonds. The other variable employed to proxy net inflows of foreign investors is the Kenya Shilling to US dollar exchange rate. For example, large foreign capital inflow is likely to strengthen the shilling against the dollar and vice versa (Krugman, 1998; Stiglitz, 2000). Thus, movements in the exchange rate may contain important information on investor flows and so by extension on movement of domestic stock liquidity.

To link all these macroeconomic factors to stock market liquidity fluctuations the study follows Brandao-Marques (2016) to specify the following econometric model:

$$
\begin{gathered}
\text { PLIQ }_{t}=\alpha_{0}+\alpha_{1} \text { PLIQ }_{t-1}+\alpha_{2} N M R E T_{t}+\alpha_{3} \text { MVOL }_{t}+\alpha_{4} I N F L_{t}+\alpha_{5} T B_{t}+ \\
\alpha_{6} \text { XRATE }_{t}+\alpha_{7} V I X_{t}+\alpha_{8} F F R_{t}+\varepsilon_{t}
\end{gathered}
$$

Where PLIQ is the one month-ahead probability of liquidity falling into a low state, NMRET is a dummy taking 1 if market returns have been negative for the previous three months, MVOL represents market return 
volatility, INFL represents inflation, TB is the three-month Treasury bill rate, XRATE represents the Kenya Shilling to U.S dollar exchange rate, VIX is the volatility index, FFR represents the Federal Funds rate which is the U.S monetary policy indicative rate, while $\varepsilon$ is the white noise disturbance term and $t$ denotes month.

\subsection{Definition of Variables}

\subsubsection{Liquidity Measures}

Monthly time series are constructed for four (il)liquidity measures namely Amihud's (2002) illiquidity ratio (ILLIQ), Liu's (2006) turnover-adjusted non-trading frequency measure, Hui-Heubel's (1984) turnover-adjusted price impact measure, and Butler et al. (2005) liquidity index. Amihud's (2002) illiquidity ratio (ILLIQ) tries to quantify the price impact of trades suggested by Kyle (1985). The ILLIQ ratio is constructed using the following formula;

$$
I L L I Q_{i, d}=\frac{\left|R_{i d}\right|}{P_{i d} V O_{i d}}
$$

Where $I L L I Q_{i, d}$ represents the daily ILLIQ measure for a particular stock, $R_{i, d}$ is the daily continuously compounded stock return, and $V O_{i, d}$ is the daily stock trading volume, $P_{i, d}$ is the daily price for stock $i$. The ILLIQ measure popular because of its ease of construction and its intuitive appeal as a measure of the price impact of order flow. On the other hand, Liu's (2006) measure focuses on the counterparty search frictions associated to market illiquidity. In particular, Liu's measure (subsequently referred as LM) is generated using the following formula:

$$
L M_{i, t}=\left[N Z D_{i, t}+\frac{1 / T R_{i, t}}{D F}\right] * \frac{21}{N_{i, t}}
$$

Where $L M_{i, t}$ denotes Liu's (2006) measure for stock $i$ in time $t$. NZZ $D_{i, t}$ represents the number of zero daily trading volumes of stock $i$ in time $t, T R_{i, t}$ is the turnover ratio of stock $i$ in time $t, N_{i, t}$ is the total number of trading days for stock $i$ in time $t$, and $D F$ is the deflator designed such that the following condition holds;

$$
0<\frac{1 / T R_{i, t}}{D F}<1
$$

Further, equation (6) has the property that if two stocks happen to have the same number of zero volume days in a period, then the turnover adjustment acts as a tie breaker. Additionally, due to variations in the total number of trading days in different months, the last term in equation (6) standardizes the trading days to 21 in each month, making comparison over time meaningful. The LM measure requires daily trading volumes and the number of outstanding firm's shares for its construction. According to Liu (2006), the attractiveness of this measure lies in its ability to capture multiple dimensions of liquidity. First, the frequency of no trade days captures the continuity of trade as well as delay or potential difficulty in executing an order. Secondly, the turnover adjustment adds the trading quantity component, that is, the measure defines a liquid security as one that turns over large quantities on a frequent basis. Thirdly, LM measure reflects the transaction cost element. By capturing the number of non-trading days (also referred to zero volume days), the measure reflects an element of trading cost. This follows the insights of Lesmond et al. (1999) who suggest that investors only trade if the value of informational signal outweighs trading costs. In this regard, the number of non-trading days is closely associated with the level of trading costs. Thus, a high proportion of zero volume days signal a high level of transaction costs in a typical exchange market

Hui and Heubel (1984)'s measure relate stock price changes to turnover. The formula for constructing this measure is as follows;

$$
H H_{i, t}=\frac{\left(\left(P^{H}-P^{L}\right) / P^{L}\right)}{V /(S * \bar{P})}
$$

Where $P^{H}$ and $P^{L}$ are the high and low prices for stock $i$ on day $t, V$ is the shillings traded volume for stock $i$ on day $t, S$ is the outstanding shares of stock $i$ on day $t$, and $\bar{P}$ is the average closing price for stock $i$ on day $t$. Like the ILLIQ measure, this measure is also averaged over some period to stabilize it. The interpretation of $\mathrm{HH}$ is that a liquid stock should not exhibit a high price variation due to a high turnover. Thus, besides reflecting price impact of trades, the $\mathrm{HH}$ measure also captures the resilience dimension of a stock's liquidity. According to Sarr and Lybek (2002), one major shortcoming of HH is that significant price changes could be due to arrival of new information and not necessarily due to illiquidity frictions.

Finally, to simultaneously capture several dimensions of illiquidity, Butler, Grullon, and Weston (2005) construct a liquidity index consisting of multiple liquidity proxies. The procedure of constructing the index is as follows: 
for each stock and liquidity measure, each observation is ranked from the least liquid to most liquid observation, next, the average of the ranks across the $\mathrm{K}$ (in our case four) liquidity measures is obtained, finally, the average rank for each observation is scaled by the number of observations, $\mathrm{N}$, to bind the liquidity index between zero (least liquid) and one (most liquid). Mathematically, the liquidity index is cast as follows:

$$
L I_{i}=\frac{1}{N} \frac{1}{K} \sum_{k=1}^{K} \operatorname{Rank}\left(X_{i, k}\right)
$$

Where $X_{i, k}$ is the kth liquidity proxy (such as TURN) for stock $i$.

\subsubsection{Liquidity Resilience}

The dependent variable shown in equation 4 as PLIIQ is obtained by first estimating the one-month ahead probability of liquidity (as measured by four proxies; ILLIQ, LM, HH, and LI) switching from a high to a low liquidity state, then this probability undergoes a logit transformation as follows:

$$
P L I Q_{t}=\log \left[\frac{p_{t}+c}{1-p_{t}+c}\right]
$$

Where $p_{t}$ is the probability of liquidity falling to a low state, $c=0.5 / N$, and $N$ is the sample size. Acharya, Amihud, and Bharath (2013) suggest that the logit transformation is motivated by the fact that probability is usually bounded between zero and one and that this property can complicate parametric estimation. To deal with this problem the probability is mapped to a real line using the cox transformation (Cox, 2018) as indicated in equation 10 .

\subsubsection{Macroeconomic Variables}

The explanatory variables include financial market variables as well as local and global macroeconomic variables. More specifically, the study controls for two widely known market variables: market returns and volatility. The market returns variable (NMRET) is constructed to capture the market downturns. That is, the NMRET is a dummy variable that takes a value of one if market return (equally weighted mean of sample stock returns) has been negative for the past three consecutive months and zero otherwise. Return volatility on the other hand is the monthly average standard deviation of daily stock return. The monthly aggregate volatility is obtained by equally weighting the standard deviation of all the sample stocks. Acharya, Amihud, and Bharath (2013) argue that declining market returns and increased volatility are associated with economic stress. Accordingly, it is hypothesized that, NMRET and VOL are increasing functions of illiquidity and hence should bear positive signs (i.e $\alpha_{2}>0$ and $\alpha_{3}>0$ ) in equation 4 .

Inflation (INFL) is measured as the monthly variation of the consumer price index (CPI). Apriori, it is expected that the coefficient on inflation should bear a positive or negative sign $\left(\alpha_{4}>0\right.$ or $\left.\alpha_{4}<0\right)$. This is because higher inflation potentially erodes the returns of stocks hence reducing participation in the stock market. However, inflation, may also indicate an economy that is associated with higher growth and hence conducive for investing in risky assets such as stocks. An occurrence that will promote trading in stocks and hence liquidity. Indeed, previous studies document mixed findings on the link between inflation and stock liquidity.

Monetary policy is proxied by the monthly variation in the 3-month Treasury bill rate (TB). Tight monetary policy (i.e. higher TB rate) implies funding constraints to potential investors as well as reduced risk appetite and hence reduced stock market activity and liquidity. Accordingly, it is expected that $\alpha_{5}>0$.

Further, three variables are employed to proxy for foreign investor flows, that is; the Kenya Shilling to U.S dollar exchange rate (XRATE), the U.S Federal Funds Rate (FFR) and the Chicago Board Exchange S\&P 500 options volatility index (VIX). This forward looking VIX index basically measures the implied (from option prices) investors' sentiments of future market conditions. This index was introduced in 1993 and is widely used to gauge the monthly global investor risk aversion. An increase in this index indicates a heightened expectation of risky conditions going forward and will typically lead to increased probability of liquidity weakening as international investors leave the risky stock markets. Similarly, increased FFR and currency depreciation (reflected by an increase in exchange rate) is likely associated with foreign equity outflows which is expected to weaken local stock liquidity. Consequently, $\alpha_{6}, \alpha_{7}$, and $\alpha_{8}$ are all expected (apriori) to be positive. Finally, following earlier empirical literature (such as (Amihud, 2002; Soderberg, 2008 among others), the study controls for persistence of liquidity by including the lagged dependent variable $\left(P L I Q_{t-1}\right)$.

\subsection{Data}

The analysis in this study utilizes monthly data covering the period January 2006 to December 2018. Particularly, for each listed stock in our sample we obtain data on; daily trading volume, daily adjusted low, high, and close 
price as well as the number of outstanding shares. The sample consists of 48 (out of 64) listed sample stocks. Monthly aggregate market returns, volatility, and liquidity measures are obtained by equally weighting monthly individual stock returns, volatility, and liquidity. The stock trade data was obtained from Datastream and verified using data from the NSE. The data on the global risk aversion VIX and FFR was obtained from the Federal Reserve Economic Database (FRED) while the local macroeconomic variables, namely, the CPI index, three-month Treasury bill, exchange rate were sourced from the Kenya National Bureau of Statistics (KNBS) and the Central Bank of Kenya (CBK) databases.

\section{Empirical Results and Discussion}

\subsection{Evolution of Liquidity Regimes}

Figure 1 plots the one-month-ahead probability of liquidity switching from a high to a low state for four liquidity proxies. Ideally, the one-step-ahead probability of low liquidity can be interpreted as the resiliency of the stock market liquidity. That is, the ability of stock liquidity to withstand adverse exogenous shocks. From Figure 1, it is observed that over the period 2006-2018, there have been about four episodes when liquidity seems to have significantly lost resilience. That is, in the periods; 2006-2007, mid 2008-2009, 2011-2012, and more recently 2015-2018.

Although the first spike on the one-month-ahead probability of low liquidity regime appears at the start of the sample study period (2006-2007), there is really no major crisis event that can be identified with this period. On the contrary, it appears that liquidity abruptly shifted from a low liquidity to a high liquidity regime. Two key factors could have potentially contributed to the remarkable improvement in liquidity over this period. Firstly, a raft of capital market reforms initiated by the Capital Markets Authority of Kenya (CMA) over the period 2002-2005 seemed to have had positive influence on liquidity. A notable component of the reforms was the introduction of a central depository and settlement (CDS) system in 2004. The CDS, by enhancing transparency, efficiency, and information flow of trading, delivery and settlement formations could have led to improved liquidity. The second factor which most probably led to a regime shift in liquidity towards the end of 2005 was the growth in economic activity over this period. The Kenyan economy remained depressed in the 1990s up to 2002. However, with a new government regime in 2003 , the economy started to recover therefore injecting new optimism to investors.

The high stock liquidity momentum at the NSE that started in 2006 continued (boosted by the introduction of an automated trading system (ATS) in June 2006) till it was interrupted in 2008-2009 period, possibly due to two factors. First, the post-election crisis that ensued in Kenya after the 2007 general election might have reduced investor confidence besides slowing economic activity in most sectors of the Kenyan economy. Secondly, the global financial crisis (GFC) that started in 2008 in the U.S and spilled over to several economies must have increased global risk aversion hence reducing participation of foreign investors (whose participation rate is high) at the NSE.
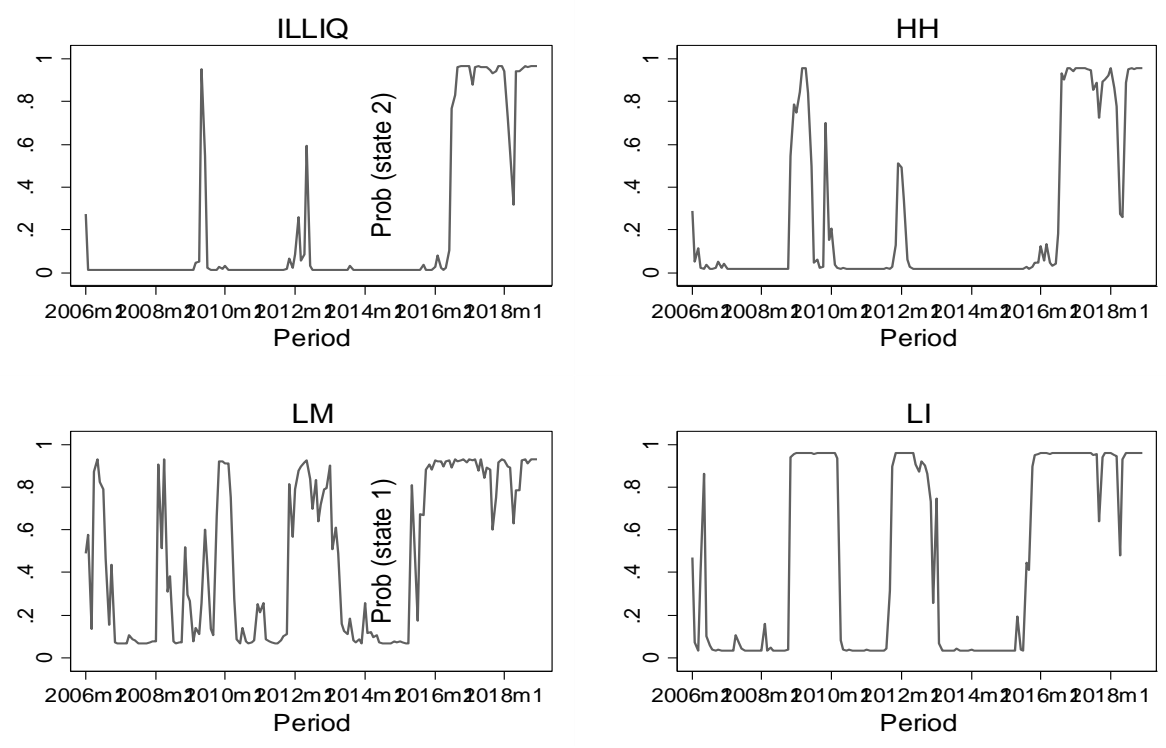

Figure 1. Probability of low stock liquidity regimes 
Figure 1 presents the time series plot of one-month-ahead probability of liquidity falling into a low liquidity regime for four liquidity measures (ILLIQ, HH, LM, and LI).

Another period when liquidity at the NSE lost resilience was in 2012. Several shocks both externally and internally could have contributed to this loss of resiliency. Externally, this period is associated with the Euro zone debt crisis that could have increased the global risk aversion consequently reducing activity in many stock markets including Kenya. Locally, inflation shocks due to oil and food price hikes, exchange rate instability in the second half of 2011, and the consequent monetary tightening could have also led to less appetite for equities and hence low stock liquidity.

Figure 1 also shows that liquidity at the NSE seems to have dissipated over the period 2015-2018. Several shocks might have contributed to the low liquidity witnessed over this period. Notably, over this period, Kenya experienced a significant depreciation of its currency against several other currencies notably the U.S dollar. For example, between 2015 and 2018, The Kenyan shilling lost about 11 percent of its value relative to the U.S dollar. Most plausibly, the collapse of commodity prices over this period as well as large foreign equity outflows could have contributed towards the fall of the Kenyan currency.

\subsection{Regression Results: Macroeconomic Determinants of Liquidity Resilience}

To explain the role of macroeconomic factors on stock market liquidity fluctuations, time series regression of model 4 was conducted. However, to ensure reliable estimates we first conduct a stationarity test to ensure our regression results are not spurious. Accordingly, Table 1 provide test statistics and the accompanying critical values of two widely used unit root tests, that is, the ADF and Philips-Perron. It is important to note that the dependent variables (PILLIQ, PHH, PLM, and PLI) in the regression models are simply scaled probabilities and thus require no stationarity tests. The main observation from Table 1 is that, except for CPI and EXRATE, all the other explanatory variables are stationary at levels. Consequently, the CPI and EXRATE variables (which were found to be stationary at first differences) enter the regression models in their first differences.

Table 1. Unit root test results

\begin{tabular}{lcccccc}
\hline Variable & ADF-Level & ADF-1st Diff & Decision & PP-Level & PP-1st Diff & Decision \\
\hline MVOL & 5.282 & & $\mathrm{I}(0)$ & -8.974 & & $\mathrm{I}(0)$ \\
LOGCPI & -0.710 & -7.374 & $\mathrm{I}(1)$ & -0.735 & -7.316 & $\mathrm{I}(1)$ \\
TB & -6.287 & & $\mathrm{I}(0)$ & -3.159 & -19.04 & $\mathrm{I}(0)$ \\
LOGXRATE & -0.765 & -9.626 & $\mathrm{I}(1)$ & -1.018 & -10.029 & $\mathrm{I}(1)$ \\
VIX & -3.638 & & $\mathrm{I}(0)$ & -3.341 & & $\mathrm{I}(0)$ \\
FFR & -3.773 & $\mathrm{I}(0)$ & -3.680 & & $\mathrm{I}(0)$ \\
\hline Critical Values & ADF & & & & \\
\hline $1 \%$ & -3.662 & & -3.648 & & \\
$5 \%$ & -2.964 & & -2.958 & & \\
$10 \%$ & -2.614 & & -2.612 & & \\
\hline
\end{tabular}

To examine the dynamics of the relationship between liquidity fluctuations and macroeconomic factors, model (4) is estimated separately for the entire sample period (2006-2018) as well as for sub-sample periods: 2006-2009, 2010-2014, and 2015-2018. The results of this exercise are reported in Table 2. Several notable observations from Table 2 are worth considering: Firstly, liquidity at the NSE exhibit strong persistence as indicated by the significantly positive coefficients on the lagged dependent variables. This observation imply that market participants can easily predict the liquidity state based on its state in the immediate previous month.

Secondly, the likelihood of liquidity entering a low-liquidity regime increases during market downturns. This is revealed by positive coefficients for the NMRET variable for most of the illiquidity measures (although it is statistically significant for only PHH and PLM). The positive coefficients on NMRET implies that, the likelihood of stock market liquidity entering a low state in the next month increases if stock market returns have been negative in the past three consecutive months. Regarding this finding, Goyenko and Ukhov (2009) plausibly explain that when stock returns are depressed, investors reallocate their portfolios towards less risky assets such as government bonds (flight to quality). For example, a flight from stock market to the bond market will lead to a decline of liquidity in the stock market while increasing liquidity in the bonds market.

Thirdly, monetary policy as measured by the three-month Treasury bill rate (TB) appears to significantly influence stock market liquidity resilience in Kenya. Over the entire sample period (first panel of Table 2), it is 
observed that the coefficient on TB is consistently positive for all liquidity measures. This implies that if the monetary authorities tighten monetary policy in the current month, the likelihood of liquidity sliding to a low regime the following month increases significantly. The sub-sample analysis provide additional findings as follows: The effect of monetary policy changes on stock liquidity fluctuations appear to be more robust and stronger over the period 2010-2018 (particularly, the 2010-2014) compared to the period 2006-2010. Plausibly, the period 2010-2018 experienced some episodes of heightened exchange rate fluctuations and the Central Bank could have significantly tightened monetary policy as a response to the large currency depreciation. It is also worth noting that, the finding that the monetary policy effects of liquidity fluctuations are less robust and even statistically insignificant in some periods ((such as the period 2006-2009) confirms Goyenko and Ukhov's (2009) argument that, unless one examines the effect of monetary shocks on liquidity over a long enough period, then most likely the researcher may find no significant relationship as he/she may fail to subsume a variety of economic shocks in the analysis.

Fifthly, the exchange rate significantly drives stock market liquidity in Kenya. Particularly, considering the entire sample period (2006-2018), the exchange rate (XRATE) bears positive coefficients indicating that depreciation of the Kenya shilling against the U.S dollar is associated with higher probability of liquidity entering a low state. Further, the sub-sample analysis reveals that the exchange rate effect on stock liquidity in Kenya has been stronger in recent years (2015-2018). One possible explanation for the association between exchange rate depreciation and stock liquidity resilience, is that, the depreciation of the currency may be caused by among other factors, large foreign equity outflows. Particularly, one stylized fact of the Kenyan stock market is the intensive participation of foreign investors. Therefore, flight of these investors is likely to depress both the Kenya shilling as well as reduce activity at the stock market.

Sixthly, as one would expect, the VIX index (used to measure the level of the global risk appetite) shows positive coefficients indicating that elevated levels of the VIX index in the current month are associated with higher likelihood of liquidity falling to a low regime in the following month. Again, the sub-sample analysis reveals some findings worth emphasizing. For example, the influence of the VIX on liquidity in the Kenyan stock market is not statistically significant at all over the period 2006-2009. This might appear surprising at first, since this period coincides with the 2008 global financial crisis (GFC), which would be associated with increased global risk aversion and by extension reduced stock activity across many markets. However, it is important to point out that, even before the GFC, foreign investors' interest on the Kenyan stock market was muted. Accordingly, there might have been a weak link between global risk appetite and the local stock liquidity over this period. In the subsequent periods, as participation of international investors grows, the VIX index starts to show some influence especially in the sub-sample period (2010-2014). This finding that increased global risk aversion leads to a decline in the Kenyan stock market is consistent with that documented for the Chilean stock market ( see Brandao-Marques, 2016).

This Table 2 presents OLS estimation results of the probability of liquidity falling into a low liquidity regime as a function of macroeconomic variables controlling for key financial market variables. The dependent variable is the probability of liquidity falling to a low regime. The probability undergoes a logit transformation to map it to a real line. This is to account for the fact that the probability is bounded between 0 and 1 . The probability is computed in the context of four liquidity measures; ILLIQ which yields PILLIQ, HH which yields PHH, LM yielding PLM, and LI which then yields PLI. The explanatory variables include; the lagged dependent variable to control for liquidity persistence, a dummy capturing a sequence of three months consecutive negative returns (NMRET), return volatility (RVOL), changes in CPI (INFL), 3-month Treasury bill rate TB), the US-Kenya Shillings exchange rate (XRATE), the global risk aversion measure (VIX) and the Federal funds rate (FFR). The sample period is January 2006 to December 2018. The table also reports, the adjusted R-squared, the model fit test (F-statistic). Additionally, to control for any unknown autocorrelation, the estimation adjusted the standard errors covariance matrix using the HAC (Newey-West) technique. Additionally, all the explanatory variables were tested for unit roots and found to be stationary. This is meant to be notes to Table 2 or can be omitted altogetether) 
Table 2. Regression results: Macroeconomic determinants of liquidity resilience

\begin{tabular}{|c|c|c|c|c|c|c|c|c|}
\hline & \multicolumn{4}{|c|}{ Sample Period: 2006M1-2018M12 } & \multicolumn{4}{|c|}{ Sample Period: $2006 \mathrm{M} 1-2009 \mathrm{M} 12$} \\
\hline & PILLIQ & PHH & PLM & PLI & PILLIQ & PHH & PLM & PLI \\
\hline Lagged dependent & $0.802 * * *$ & $0.873 * * *$ & $0.764 * * *$ & $0.847 * * *$ & $0.601 * * *$ & $0.734 * * *$ & $0.509 * * *$ & $0.621 * * *$ \\
\hline NMRET & -0.074 & $0.322 * *$ & 0.149 & 0.271 & 1.019 & $1.569^{* *}$ & $1.788 * *$ & 0.709 \\
\hline MVOL & 5.524 & -4.025 & -1.656 & 9.752 & -6.543 & -10.206 & -21.532 & -1.339 \\
\hline INFL & 8.36 & 12.368 & -3.033 & -0.3 & -1.714 & $40.516^{*}$ & -2.941 & -1.617 \\
\hline ТВ & $0.051 * *$ & $0.057 * * *$ & $0.064 * * *$ & $0.077 * * *$ & -0.738 & 0.588 & 0.087 & 0.003 \\
\hline XRATE & $0.04 * *$ & $0.030 * * *$ & $0.022 * *$ & $0.029 * * *$ & 0.023 & $0.186^{* *}$ & 0.043 & 0.092 \\
\hline VIX & 0.027 & $0.039 * * *$ & 0.011 & $0.04 * * *$ & -0.008 & -0.033 & -0.044 & 0.001 \\
\hline FFR & 0.105 & $0.153^{* *}$ & 0.066 & 0.072 & $0.318^{*}$ & 0.132 & -0.184 & -0.278 \\
\hline Constant & -4.88 & -3.982 & -2.612 & -4.378 & $4.111 * * *$ & -17.203 & -1.842 & -6.182 \\
\hline $\mathrm{N}$ & 155 & 155 & 155 & 155 & 47 & 47 & 47 & 47 \\
\hline \multirow[t]{2}{*}{ F-Statistic } & 96.326 & 167.731 & 47.115 & 148.062 & 10.568 & 22.357 & 4.103 & 27.533 \\
\hline & {$[0.0000]$} & {$[0.0000]$} & [0.0000] & {$[0.0000]$} & {$[0.0000]$} & {$[0.0000]$} & {$[0.0000]$} & [0.0000] \\
\hline \multirow[t]{3}{*}{ R-Squared } & 0.832 & 0.896 & 0.875 & 0.884 & 0.624 & 0.788 & 0.350 & 0.852 \\
\hline & \multicolumn{4}{|c|}{ Sample Period: 2010M1-2014M12 } & \multicolumn{4}{|c|}{ Sample Period: 2015M1-2018M12 } \\
\hline & PILLIQ & $\mathrm{PHH}$ & PLM & PLI & PILLIQ & $\mathrm{PHH}$ & PLM & PLI \\
\hline Lagged dependent & $0.557 * * *$ & $0.628 * * *$ & $0.716^{* * *}$ & $0.895 * * *$ & $0.728 * * *$ & $0.757 * * *$ & 0.148 & $0.717 * * *$ \\
\hline NMRET & -0.458 & 0.928 & -1.224 & 0.663 & -0.18 & $0.187 *$ & $0.699 * * *$ & 0.225 \\
\hline RVOL & -72.59 & 4.316 & 23.237 & -0.935 & 19.419 & 9.706 & 0.256 & 21.066 \\
\hline INFL & 23.921 & 14.567 & 22.777 & -1.774 & -1.037 & 1.093 & 17.142 & 9.102 \\
\hline TB & $0.169 * * *$ & $0.125^{* *}$ & $0.127^{* * *}$ & 0.035 & -0.064 & $0.072 * * *$ & -0.048 & $0.111^{* *}$ \\
\hline XRATE & -0.035 & $0.135^{* *}$ & -0.005 & 0.014 & $0.161^{* *}$ & $0.122 * *$ & $0.341^{* * *}$ & $0.136^{* *}$ \\
\hline VIX & $0.062 * * *$ & $0.089 * *$ & 0.035 & $0.045^{* *}$ & $0.071^{*}$ & 0.001 & 0.0157 & -0.024 \\
\hline FFR & -2.076 & 6.702 & 5.08 & -5.781 & 0.067 & 0.113 & 0.033 & 0.23 \\
\hline Constant & 1.325 & $7.795^{*}$ & -2.707 & -1.886 & -16.826 & -12.802 & -33.172 & -14.6 \\
\hline $\mathrm{N}$ & 60 & 60 & 60 & 60 & 48 & 48 & 48 & 48 \\
\hline \multirow[t]{2}{*}{ F-Statistic } & 25.231 & 80.59 & 59.92 & 56.906 & 25.231 & 80.59 & 14.54 & 56.906 \\
\hline & {$[0.0000]$} & {$[0.0000]$} & {$[0.0000]$} & {$[0.0000]$} & {$[0.0000]$} & {$[0.0000]$} & {$[0.0000]$} & [0.0000] \\
\hline R-Squared & 0.766 & 0.92 & 0.904 & 0.883 & 0.766 & 0.92 & 0.904 & 0.883 \\
\hline
\end{tabular}

$* * * \mathrm{p}<0.01, * * \mathrm{p}<0.05, * \mathrm{p}<0.1$.

Seventhly, tightening of U.S monetary policy (FFR) seems to break the resilience of the local stock liquidity. This is shown by the positive coefficients on FFR, implying that tight U.S monetary policy increases the likelihood of liquidity switching to a low regime. This result is consistent with the flight to quality phenomenon. For example, when the Federal Reserve Bank raises interest rates, international investors often tend to shift their portfolios away from risky assets in emerging and frontier markets into the safe (and now high yielding) assets in the U.S. The possibly large capital outflows from the emerging markets may cause high price impact of trades particularly in thinly traded markets. Additionally, in some markets such as NSE, where foreign trading accounts for a significant percentage of daily equity turnover, flight of foreign investors can largely mute trading activity. The empirical evidence in this chapter on the role of FFR in influencing liquidity at the NSE appears statistically weak however. Overall, only PHH show a statistically significant positive coefficients while only PILLLIQ bear a positive and significant (at 10 percent significance level) coefficient during the period 2006-2009.

Lastly, domestic inflation does not seem to influence stock market liquidity changes in Kenya over the sample period considered. Previous studies (from other countries) provide mixed results with some documenting that inflation significantly impedes liquidity (notably, Goyenko \& Ukhov, 2009; Marcelo et al., 2015; Rehman et al., 2016) while others conclude that inflation has negligible impact on liquidity (see Fujimoto, 2003; Soderberg, 2008; Brandao-Marques, 2016).

\subsection{Robustness Check: Stock Size Portfolios}

To test the robustness of the results obtained in section 4.3, model (4) is run separately for large stocks and small stocks. Specifically, all the sample stocks are split into three groups based on their market capitalization. Then model 4 is conducted for the large and small sized-stocks separately. The results for this estimation are reported in Table 2. There are two key findings from this exercise: first, the regressions results are not very robust, when 
the stocks are analyzed at portfolio level. This might arise for example if individual effects of the stocks are prominent therefore overshadowing the influence of the macroeconomic factors. Second, the role of market down turns, domestic monetary policy, and the global risk aversion remains significant especially for large stocks. This second observation is to be expected since trading at the NSE is dominated by a few large stocks.

Table 3. Regression results: Macroeconomic determinants of liquidity resilience by stock size groups (2006-2018)

\begin{tabular}{lllllllll}
\hline & Large & Small & Large & Small & Large & Small & Large & Small \\
\cline { 2 - 9 } & PILLIQ & PILLIQ & PHH & PHH & PLM & PLM & PLM & PLM \\
\hline Lagged dep & $0.858^{* * *}$ & $0.937 * * *$ & $0.712^{* * *}$ & $0.968^{* * *}$ & $0.597 * * *$ & $0.887 * * *$ & $0.872^{* * *}$ & $0.814^{* * *}$ \\
NMRET & 0.193 & 0.029 & $0.567 * * *$ & 0.458 & $0.487 * * *$ & 0.208 & $0.564 * * *$ & 0.276 \\
MVOL & 6.498 & 8.616 & 4.875 & 8.331 & -16.764 & 14.091 & 11.416 & 10.734 \\
INFL & -5.074 & 4.741 & -3.737 & 3.407 & -1.486 & -2.518 & 1.402 & 0.397 \\
TB & 0.031 & $0.057 * *$ & 0.029 & 0.035 & $0.063 * *$ & 0.027 & $0.036^{* *}$ & $0.065^{* *}$ \\
XRATE & -3.956 & -1.759 & -8.533 & -2.077 & 0.945 & -2.201 & -3.911 & 2.207 \\
VIX & $0.023^{* * *}$ & 0.006 & $0.019 * *$ & -0.001 & -0.001 & -0.006 & $0.019 * *$ & 0.018 \\
FFR & 0.014 & -0.032 & 0.085 & -0.044 & -0.039 & -0.096 & 0.008 & -0.051 \\
Constant & -1.368 & -0.857 & -0.638 & -0.546 & 0.328 & -0.316 & -1.098 & -1.139 \\
N & 155 & 155 & 155 & 155 & 155 & 155 & 155 & 155 \\
F-Statistic & 14.796 & 154.24 & 37.005 & 476.12 & 19.158 & 100.974 & 100.29 & 167.345 \\
& {$[0.0000]$} & {$[0.0000]$} & {$[0.0000]$} & {$[0.0000]$} & {$[0.0000]$} & {$[0.0000]$} & {$[0.0000]$} & {$[0.0000]$} \\
R-Squared & 0.417 & 0.791 & 0.652 & 0.761 & 0.694 & 0.823 & 0.739 & 0.826 \\
\hline
\end{tabular}

$* * * \mathrm{p}<0.01, * * \mathrm{p}<0.05, * \mathrm{p}<0.1$.

\section{Conclusions}

This paper set out to examine the linkage between stock market liquidity changes and the macro economy by taking the case of Kenya over the period January 2006 to December 2018. Although there exist few studies which examine this relationship for other markets, Soderberg (2008) notes that the relationship appears to vary across markets. Therefore, this study makes an important contribution to the financial economics literature by focusing on an order driven market that has not been studied before. To achieve this objective, the study first estimates the probability of stock liquidity being in either high or low state using a Markov regime switching model in the style of Hamilton (1989). Next, the study identifies periods when liquidity fell into a low liquidity state. Finally, the probability of the low liquidity regimes is associated with some observable global and domestic macroeconomic conditions.

From the empirical evidence obtained in this study, the following can be concluded: Firstly, the Markov regime switching model significantly delineates two liquidity regimes in the Kenyan stock market over the sample period. In this regard, four major episodes of significantly low liquidity states are identified. These episodes include; 2006-2007; the 2008-2009 global financial crisis, during the 2011-2012 possibly as a result of a combination of local shocks and global shocks. And more recently, during the 2015-2018 period when currency depreciation shocks hit the Kenyan economy.

Secondly, the empirical results show that macroeconomic conditions matter for liquidity. Domestically, tight monetary policy and currency depreciation significantly predict a decline in local stock market liquidity. Globally, elevated risk aversion appears to be associated with low liquidity resilience. Further, the empirical evidence in this study also reveals that liquidity is likely to lose resilience during local market downturns.

These empirical findings have implications for investors and policy authorities. For investors, the results imply that understanding the developments in local as well as global macroeconomic conditions can help in not only designing trading strategies (especially based on liquidity) but also monitoring their liquidity exposures. Simply, understanding the macroeconomic determinants of liquidity fluctuations help investors make informed investment choices which ultimately lead to efficient resource allocation. For financial markets supervisors, the empirical findings provide useful information as to which particular variables to watch in performing their surveillance duties. For instance, the finding that domestic monetary policy drives the cyclical behavior of stock liquidity in Kenya calls for monetary policy authorities to incorporate stock liquidity into their monetary policy reaction function. The study however also finds that global conditions including global risk appetite explain the cyclical fluctuations of stock liquidity in Kenya. Although these are external shocks and Kenya does not have 
influence on them, it can attempt to structurally improve local stock liquidity. Kenya can for instance try to grow the local investor base so that trading activity is not dominated by foreign investors.

Although this study meets its main objective, the empirical results obtained leave open an important question that can be fruitfully explored in future. That is, what are the channels through which macroeconomic variables impact liquidity? Indeed, this question is relevant not only for Kenya but for all order driven markets. The existing theories linking macroeconomic variables and liquidity rely on the existence of liquidity providers such as market makers. However, such agents do not exist in order driven markets. So, by what mechanism does monetary policy for instance impact stock liquidity? This question is left for future research.

\section{References}

Acharya, V., Amihud, Y., \& Bharath. (2013). Liquidity risk of corporate bond returns: Conditional approach. Journal of Financial Economics, 110(2), 358-386. https://doi.org/10.1016/j.jfineco.2013.08.002

Adjasi, C. K., \& Yartey, C. A. (2007). Stock market development in Sub-Saharan Africa: Critical issues and challenges. International Monetary Fund. https://doi.org/10.5089/9781451867732.001

Agudelo, D. (2010). Friend of foe? Foreign investors and the liquidity of six Asian markets. Asia-Pacific Journal of Financial Studies, 39, 261-300. https://doi.org/10.1111/j.2041-6156.2010.01012.x

Amihud, Y. (2002). Illiquidity and stock returns: Cross-section and time-series effects. Journal of Financial Markets, 5(1), 31-56. https://doi.org/10.1016/S1386-4181(01)00024-6

Amihud, Y., \& Mendelson, H. (1986). Asset pricing and the bid-ask spread. Journal of Financial Economics, 17(2), 223-249. https://doi.org/10.1016/0304-405X(86)90065-6

Bencivenga, V. R., \& Smith, B. D. (1991). Financial intermediation and endogenous growth. The Review of Economic Studies, 58(2), 195-209. https://doi.org/10.2307/2297964

Brandao-Marques, L. (2016). Stock Market Liquidity in Chile. https://doi.org/10.5089/9781475554656.001

Brockman, P., \& Chung, D. Y. (2002). Commonality in Liquidity: Evidence from an Order-Driven Market Structure. Journal of Financial Research, 25(4), 521-539. https://doi.org/10.1111/1475-6803.00035

Brockman, P., Chung, D. Y., \& Pérignon, C. (2009). Commonality in liquidity: A global perspective. Journal of Financial and Quantitative Analysis, 44(04), 851-882. https://doi.org/10.1017/S0022109009990123

Brunnermeier, M. K., \& Pedersen, L. H. (2009). Market liquidity and funding liquidity. Review of Financial Studies, 22(6), 2201-2238. https://doi.org/10.1093/rfs/hhn098

Butler, A. W., Grullon, G., \& Weston, J. P. (2005). Stock Market Liquidity and the Cost of Issuing Equity. Journal of Financial and Quantitative Analysis, 40(2), 331-348. https://doi.org/10.1017/S0022109000002337

Chordia, T., Roll, R., \& Subrahmanyam, A. (2000). Commonality in liquidity. Journal of Financial Economics, 56(1), 3-28. https://doi.org/10.1016/S0304-405X(99)00057-4

Chordia, T., Roll, R., \& Subrahmanyam, A. (2001). Market liquidity and trading activity. The Journal of Finance, 56(2), 501-530. https://doi.org/10.1111/0022-1082.00335

Chordia, T., Sarkar, A., \& Subrahmanyam, A. (2005). An empirical analysis of stock and bond market liquidity. Review of Financial Studies, 18(1), 85-129. https://doi.org/10.1093/rfs/hhi010

Cox, D. R. (2018). Analysis of binary data. Routledge. https://doi.org/10.1201/9781315137438

Datar, V. T., Naik, N. Y., \& Radcliffe, R. (1998). Liquidity and stock returns: An alternative test. Journal of Financial Markets, 1(2), 203-219. https://doi.org/10.1016/S1386-4181(97)00004-9

Debata, B., \& Mahakud, J. (2018). Interdependence between Monetary Policy and Stock Liquidity: A Panel VAR Approach. Margin: The Journal of Applied Economic Research, 12(4), 387-413. https://doi.org/10.1177/0973801018786270

Ding, M., Nilsson, B., Suardi, S., \& others. (2013). Foreign institutional investors and stock market liquidity in China: State ownership, trading activity and information asymmetry. The Knut Wicksell Centre for Financial Studies, Lund University Working Paper, 14. https://doi.org/10.2139/ssrn.2241832

Eisfeldt, A. L. (2004). Endogenous liquidity in asset markets. The Journal of Finance, 59(1), 1-30. https://doi.org/10.1111/j.1540-6261.2004.00625.x

Ellington, M., Florackis, C., \& Milas, C. (2017). Liquidity shocks and real GDP growth: Evidence from a 
Bayesian time-varying parameter VAR. Journal of International Money and Finance, 72, 93-117. https://doi.org/10.1016/j.jimonfin.2016.12.002

Fernández-Amador, O., Gächter, M., Larch, M., \& Peter, G. (2013). Does monetary policy determine stock market liquidity? New evidence from the euro zone. Journal of Empirical Finance, 21, 54-68. https://doi.org/10.1016/j.jempfin.2012.12.008

Fernando, C. S. (2003). Commonality in liquidity: Transmission of liquidity shocks across investors and securities. Journal of Financial Intermediation, $233-254$. https://doi.org/10.1016/S1042-9573(03)00041-X

Flood, M. D., Liechty, J. C., \& Piontek, T. (2015a). Systemwide Commonalities in Market Liquidity (No. 15-11; Working Papers). Office of Financial Research, US Department of the Treasury. https://doi.org/10.2139/ssrn.2612348

Flood, M. D., Liechty, J., \& Piontek, T. (2015b). Systemwide commonalities in market liquidity. https://doi.org/10.2139/ssrn.2612348

Fujimoto, A. (2003). Macroeconomic sources of systematic liquidity. Unpublished Working Paper, Yale University.

Galariotis, E., \& Giouvris, E. (2015). On the stock market liquidity and the business cycle: A multi country approach. International Review of Financial Analysis, 38, 44-69. https://doi.org/10.1016/j.irfa.2015.01.009

Goyenko, R. Y., \& Ukhov, A. D. (2009). Stock and Bond Market Liquidity: A Long-Run Empirical Analysis. Journal of Financial and Quantitative Analysis, 44(01), 189. https://doi.org/10.1017/S0022109009090097

Hamilton, J. D. (1989a). A New Approach to the Economic Analysis of Nonstationary Time Series and the Business Cycle. Econometrica, 57(2), 357. https://doi.org/10.2307/1912559

Hamilton, J. D. (1989b). A new approach to the economic analysis of nonstationary time series and the business cycle. Econometrica: Journal of the Econometric Society, 357-384. https://doi.org/10.2307/1912559

Haroon, O., \& Rizvi, S. A. R. (2020). Flatten the curve and stock market liquidity-an inquiry into emerging economies. Emerging Markets Finance and Trade, 56(10), 2151-2161. https://doi.org/10.1080/1540496X.2020.1784716

Hasbrouck, J., \& Seppi, D. J. (2001). Common factors in prices, order flows, and liquidity. Journal of Financial Economics, 59(3), 383-411. https://doi.org/10.1016/S0304-405X(00)00091-X

Hearn, B. (2009). Liquidity estimation in major African equity markets. Cairo and Alexandria Stock Exchange Occasional Paper Series, 6. https://doi.org/10.2139/ssrn.1345270

Hearn, B., Piesse, J., \& Strange, R. (2010). Market liquidity and stock size premia in emerging financial markets: The implications for foreign investment. International Business Review, 19(5), 489-501. https://doi.org/10.1016/j.ibusrev.2009.02.009

Huberman, G., \& Halka, D. (2001). Systematic liquidity. Journal of Financial Research, 24(2), 161-178. https://doi.org/10.1111/j.1475-6803.2001.tb00763.x

Hui, B., \& Heubel, B. (1984). Comparative liquidity advantages among major US stock markets (Vol. 84081). Data Resources inc.

Koch, A., Ruenzi, S., \& Starks, L. (2016). Commonality in liquidity: A demand-side explanation. Review of Financial Studies, hhw026. https://doi.org/10.1093/rfs/hhw026

Krugman, P. R. (1998). What happened to Asia? Audio-Visual Centre, University of Auckland. https://doi.org/10.1007/978-1-4615-5109-6_14

Kurihara, Y. (2017). Monetary Policy and Stock/Foreign Exchange Market Liquidity: The Japanese Case. Journal of Economics Library, 4(1), 1-8. https://doi.org/10.1453/jel.v4i1.1222

Lee, J., Ryu, D., \& Kutan, A. M. (2016). Monetary policy announcements, communication, and stock market liquidity. Australian Economic Papers, 55(3), 227-250. https://doi.org/10.1111/1467-8454.12069

Lesmond, D. A., Ogden, J. P., \& Trzcinka, C. A. (1999). A new estimate of transaction costs. Review of Financial Studies, 12(5), 1113-1141. https://doi.org/10.1093/rfs/12.5.1113

Marcelo, J. L. M., Quirós, M. del M. M., \& Oliveira, C. (2015). Systematic liquidity: Commonality and inter-temporal variation in the Portuguese stock market. Cuadernos de Gestión, 15(2), 39-64. 
https://doi.org/10.5295/cdg.140472mm

Massa, M. (2004). Mutual Fund Competition and Stock Market Liquidity [Working Paper]. INSEAD.

Minovic, J., \& Zivkovic, B. (2012). The impact of liquidity and size premium on equity price formation in Serbia. Economic Annals, 57(195), 43-78. https://doi.org/10.2298/EKA1295043M

Nwaolisa, E. F., \& Chijindu, A. A. (2016). The relationship between index of industrial production and stock market liquidity: A Co-integration evidence from Stock exchange of Nigeria's value of stock traded ratio. Frontiers of Accounting and Finance, 1(1).

Nyasha, S., \& Odhiambo, N. M. (2014). The dynamics of stock market development in Kenya. Journal of Applied Business Research, 30(1), 73. https://doi.org/10.19030/jabr.v30i1.8284

Pukthuanthong-Le, K., \& Visaltanachoti, N. (2009). Commonality in liquidity: Evidence from the Stock Exchange of Thailand. Pacific-Basin Finance Journal, 17(1), 80-99. https://doi.org/10.1016/j.pacfin.2007.12.004

Rehman, I., Shahnaz, N., \& Zainudin, R. (2016). Is the relationship between macroeconomy and stock market liquidity mutually reinforcing? Evidence from an emerging market. International Journal of Monetary Economics and Finance, 9(3). https://doi.org/10.1504/IJMEF.2016.078405

Sarr, A., \& Lybek, T. (2002). Measuring liquidity in financial markets. Retrieved from http://papers.ssrn.com/sol3/papers.cfm?abstract_id=880932

Soderberg, J. (2008). Do macroeconomic variables forecast changes in liquidity? An out-of-sampe study on the order driven stock markets in Scandinavia (Working Paper No. 10). Vaxjo University.

Stiglitz, J. E. (2000). Capital market liberalization, economic growth, and instability. World Development, 28(6), 1075-1086. https://doi.org/10.1016/S0305-750X(00)00006-1

Zheng, X., \& Su, D. (2017). Impacts of oil price shocks on Chinese stock market liquidity. International Review of Economics \& Finance, 50, 136-174. https://doi.org/10.1016/j.iref.2017.03.021

\section{Copyrights}

Copyright for this article is retained by the author(s), with first publication rights granted to the journal.

This is an open-access article distributed under the terms and conditions of the Creative Commons Attribution license (http://creativecommons.org/licenses/by/4.0/). 